\title{
$\widehat{A}$ Madridge
}

madridge Journal of Nanotechnology \& Nanoscience

\author{
Interconnecting Scientific World
}

Research Article

Open Access

\section{Antimicrobial activity of Chemically Synthesized Sn and Sr Doped Cadmium and Zinc Sulphides Semiconductor Nanoparticles}

\author{
Madhuri M Bhagat*, PB Lokhande and HA Mujawar \\ Department of Chemistry, Dr. Babasaheb Ambedkar Technological University, Lonere, Raigad, Maharashtra, India
}

\section{Article Info}

\author{
*Corresponding author: \\ Madhuri M Bhagat \\ Department of Chemistry \\ Dr. Babasaheb Ambedkar Technological \\ University \\ Lonere, Raigad, Maharashtra \\ India \\ E-mail: madhurisd16@gmail.com
}

Received: February 27, 2019

Accepted: March 12, 2019

Published: March 18, 2019

Citation: Bhagat $\mathrm{MM}$, Lokhande $\mathrm{PB}$, Mujawar HA. Antimicrobial activity of Chemically Synthesized Sn and Sr Doped Cadmium and Zinc Sulphides Semiconductor Nanoparticles. Madridge J Nanotechnol Nanosci. 2019; 4(1): 135-138.

doi: 10.18689/mjnn-1000127

\begin{abstract}
Copyright: @ $₫ 2019$ The Author(s). This work is licensed under a Creative Commons Attribution 4.0 International License, which permits unrestricted use, distribution, and reproduction in any medium, provided the original work is properly cited.
\end{abstract}

Published by Madridge Publishers

\begin{abstract}
With increasing applications of semiconductor, antimicrobial activity is also taking the attraction of researchers. Cadmium Sulphide and Zinc Sulphide semiconducting nanoparticles are used as antimicrobial agent. Sn and Sraffect the property of antimicrobial activity. The Sn and Sr doped Cadmium Sulphide and Tin Sulphide has been prepared by Chemical Co-precipitation method and Sol-Gel method respectively for the formation of high crystallinity. The Morphological study was carried out by Scanning Electron Microscopy, the elemental analysis was studied by Energy Dispersive X-ray analysis and Crystal study laws performed by $\mathrm{X}$ - Diffraction technique. The antimicrobial activity of Cadmium Sulphide and Zinc Sulphide is affected by the Sn and Sr doping.
\end{abstract}

Keywords: Antimicrobial activity; Semiconducotr; Nanoparticles; Crystallinity.

\section{Introduction}

Semiconductor nanoparticles have wide range of applications. Due to possessing variable physical, chemical, structural and optical properties, they can be used in solar cells, for the removal of water pollution, for the generation of hydrogen gas via water splitting, in medicines, in paints and in LEDs. Apart from that is also be used as an antimicrobials [1]. The role of using as antimicrobial to kill the microorganisms hereby enhances the function of food packaging for the maintenance of quality [2].

Antimicrobial activity of Cadmium Sulphide, Zinc Sulphide, Zinc oxide and Copper oxides Titanium Dioxide, has been extensively studied by the earlier researchers. Cadmium sulphide and Zinc Sulphide are the II-IV group semiconductors having the band gaps of $2.42 \mathrm{eV}$ and $3.7 \mathrm{eV}$ respectively. On doping with impurities like metals they show variable structural and optical properties. The variation upon doping with metal ions may also have the effect on the antimicrobial activities [3,4].

In present work the antimicrobial activity of Cadmium Sulphide and Zinc Sulphide has been studied. The Cadmium Sulphide and Zinc Sulphide affects the antimicrobial activity unlike other photocatalytic activity when doped with Strontium and Tin. For the sec of better nanoparticles size Cadmium Sulphide nanoparticles were prepared by Chemical co- precipitation method and Zinc Sulphide nanoparticles by sol-gel method. The Cadmium Sulphide and zinc sulphide both were doped with $\mathrm{Sr}$ and Tin with different proportions [4-6].

The antimicrobial test was performed on Staphylococcus aureus, Salmonella Typhi, Pseudomonas and Escherichia coli microbes. Staphylococcus aureus is the common cause of skin infections including abscesses, respiratory infections such as sinusitis, and food poisoning, Salmonella Typhi is reason for the development of Typhoid or entric fever, Pseudomonas are 
considered opportunistic and some kinds of Escherichia coli can cause diarrhea, while others cause urinary tract infections, respiratory illness and pneumonia, and other sickness $[7,8]$.

\section{Materials and Methods}

\section{Synthesis and characterization of $\mathrm{Sn}$ and $\mathrm{Sr}$ doped cadmium sulphide}

Cadmium sulphide nanoparticles doped with Strontium $(\mathrm{Sr})$ and Tin (Sn) were prepared by Chemical co-precipitation method. The chemicals used were of AR grade. Four samples $(A, B, C, D)$ of different concentrations of Strontium (Sr) and Tin (Sn) were prepared by varying the concentrations of $\mathrm{Sn}$ and $\mathrm{Sr}$ from $0.02 \mathrm{M}$ to $0.08 \mathrm{M}$ by using the formula $\left(\mathrm{Sn}_{\mathrm{x}} \mathrm{Sr}_{\mathrm{y}} \mathrm{Cd}_{1-\mathrm{x}+\mathrm{y}} \mathrm{S}\right)$. For the synthesis of sample an appropriate proportion of Strontium Nitrate $\mathrm{Sr}\left(\mathrm{NO}_{3}\right)_{2}$, Stannous Chloride dihydrate $\mathrm{SnCl}_{2} .2 \mathrm{H}_{2} \mathrm{O}$, Cadmium acetate $\mathrm{Cd}\left(\mathrm{CH}_{3} \mathrm{COO}\right)_{2}$ dihydrate, and Thiourea $\mathrm{CS}\left(\mathrm{NH}_{2}\right)_{2}$ were used for the synthesis of doped photocatalyst. Pure Cadmium Sulphide was also prepared by using Cadmium Acetate and Thiourea.

Calculated quantity of all the reactants was dissolved in $100 \mathrm{ml}$ distilled water and then the mixture of Cadmium acetate, stannous chloride and strontium nitrate was stirred for 10 minutes on magnetic stirrer. After 10 minutes the Thiourea solution was added drop wise to this mixture in to this mixture and the $\mathrm{pH}$ of solution was adjusted to 11 by adding the ammonia solution. This mixture was stirred for 1 hour at the temperature of $70^{\circ} \mathrm{C}$. The yellow precipitate was formed after one hour. The precipitate was then filtered, washed with water and ethanol several times and dried in an oven.

\section{Synthesis and characterisation of Sn and Sr doped zinc sulphide}

The Tin and Strontium doped Zinc Sulphide was synthesized by Sol-Gel method. For the Pure Zinc Sulphide synthesis, Zinc Acetate dihydrate $\mathrm{Zn}\left(\mathrm{CH}_{3} \mathrm{COO}\right)_{2} \cdot 2 \mathrm{H}_{2} \mathrm{O}$ and Thiourea $\left(\mathrm{CS}\left(\mathrm{NH}_{2}\right)_{2}\right)$ were taken in a molar proportion $(0.1 \mathrm{M})$. For the doping of metals Strontium and Tin, Strontium Nitrate $\operatorname{Sr}\left(\mathrm{NO}_{3}\right)_{2}$ and Stannous Chloride $\mathrm{SnCl}_{2} \cdot 2 \mathrm{H}_{2} \mathrm{O}$ were taken respectively. Four samples of different proportions A-( $\left.\mathrm{Sn}_{0.02}, \mathrm{Sr}_{0.08}: \mathrm{ZnS}\right), \mathrm{B}-\left(\mathrm{Sn}_{0.04}\right.$, $\left.\mathrm{Sr}_{0.06}: \mathrm{ZnS}\right), \mathrm{C}-\left(\mathrm{Sn}_{0.06}, \mathrm{Sr}_{0.04}: \mathrm{ZnS}\right)$ and D-(Sn $\left.\mathrm{S}_{0.08}, \mathrm{Sr}_{0.02}: \mathrm{ZnS}\right)$ were prepared. These samples were prepared by applying the molar proportion formula $\mathrm{Zn}_{\mathrm{x}} \mathrm{Sn}_{\mathrm{y}} \mathrm{Sr}_{(1-\mathrm{x}+\mathrm{y})} \mathrm{S}$.

For the preparation of doped Zinc Sulphide, appropriate weights of required chemicals were dissolved in $100 \mathrm{ml}$ methanol. Firstly Solutions of Zinc Acetate, Strontium Nitrate and Stannous Chloride were mixed and stirred on the magnetic stirrer for 10 minutes. Then Thiourea solution was added drop wise for proper nucleation. $25 \mathrm{ml}$ ethylene glycol was also added as a capping agent. The temperature was raised to $80^{\circ} \mathrm{C}$. This mixture was continuously stirred for 6 hours. Initially colourless sol is form which was then turned to pink colour gel. This gel was dried on magnetic stirrer and calcined at $750^{\circ} \mathrm{C}$ in muffle furnace for an hour. After Calcination product were collected and taken for characterization. Same procedure was repeated for the synthesis of pure zinc sulphide by using zinc acetate dihydarte and thiourea.

\section{Results and Discussion}

\section{Characterisation}

The cadmium sulphide and zinc sulphide nanoparticles were characterised by sanning electron microscopy, energy dispersive $x$-ray technique and $\mathrm{x}$-ray diffraction technique.

\section{Scanning electron microscopy}

Morphological study and the size the nanoparticles of Sn and $\mathrm{Sr}$ doped cadmium and zinc sulphide was carried out by scanning electron microscopy. The figures 1 and 2 are the SEM images of Sn amd Sr doped cadmium and zinc sulphide nanoparticles.
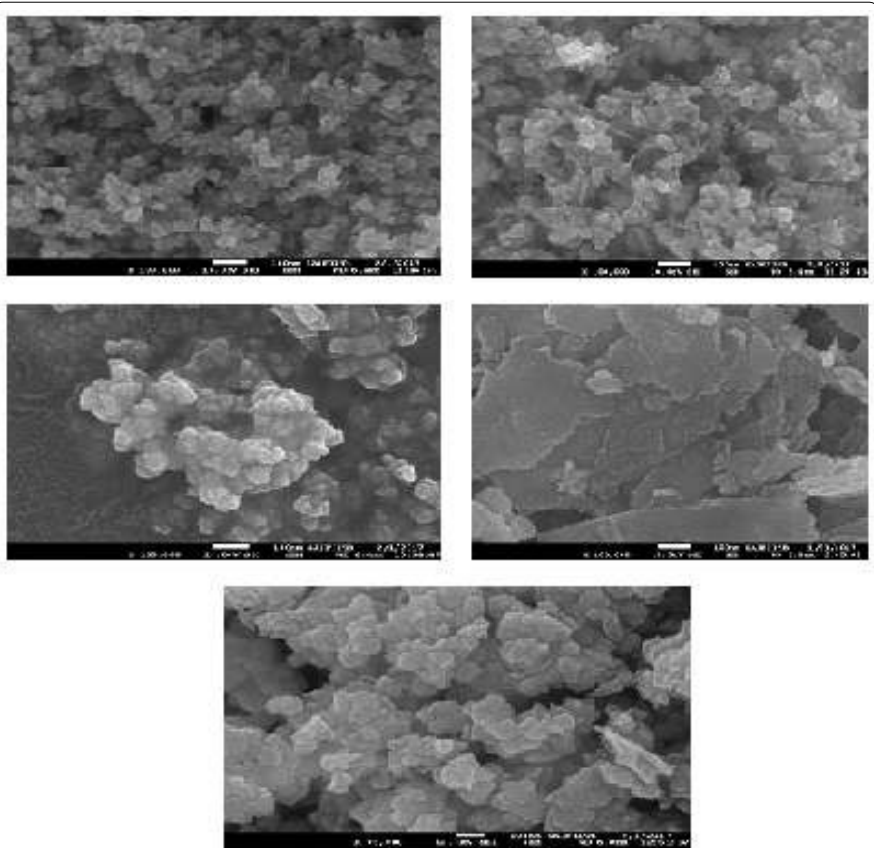

Figure 1. SEM images of A-(Sn0.02, Sr0.08: CdS), B-(Sn0.04, Sr0.06: CdS), C-(Sn0.06, Sr0.04:CdS), D-(Sn0.08, Sr0.02: CdS) and E-Pure $\mathrm{CdS}$ respectively.
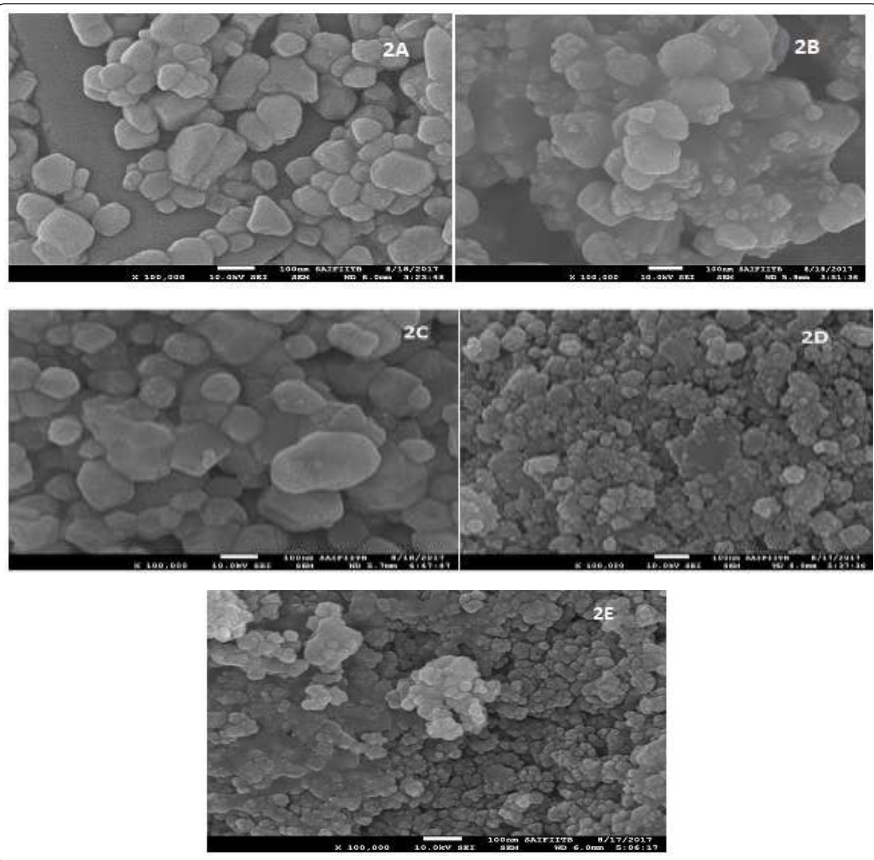

Figure 2. SEM images of $A-\left(\mathrm{Sn}_{0.02}, \mathrm{Sr}_{0.08}: \mathrm{ZnS}\right), \mathrm{B}-\left(\mathrm{Sn}_{0.04}, \mathrm{Sr}_{0.06}: \mathrm{ZnS}\right)$, $\mathrm{C}-\left(\mathrm{Sn}_{0.06}, \mathrm{Sr}_{0.04}: \mathrm{ZnS}\right), \mathrm{D}-\left(\mathrm{Sn}_{0.08}, \mathrm{Sr}_{0.02}: \mathrm{ZnS}\right)$ and E-Pure $\mathrm{ZnS}$ respectively. 


\section{Energy dispersive $x$-ray}

Elemental analysis of synthesized $\mathrm{Sn}$ and $\mathrm{Sr}$ doped cadmium sulphide and zinc sulphide nanoparticles were carried out by Energy dispersive X-ray technique (Figure 3).
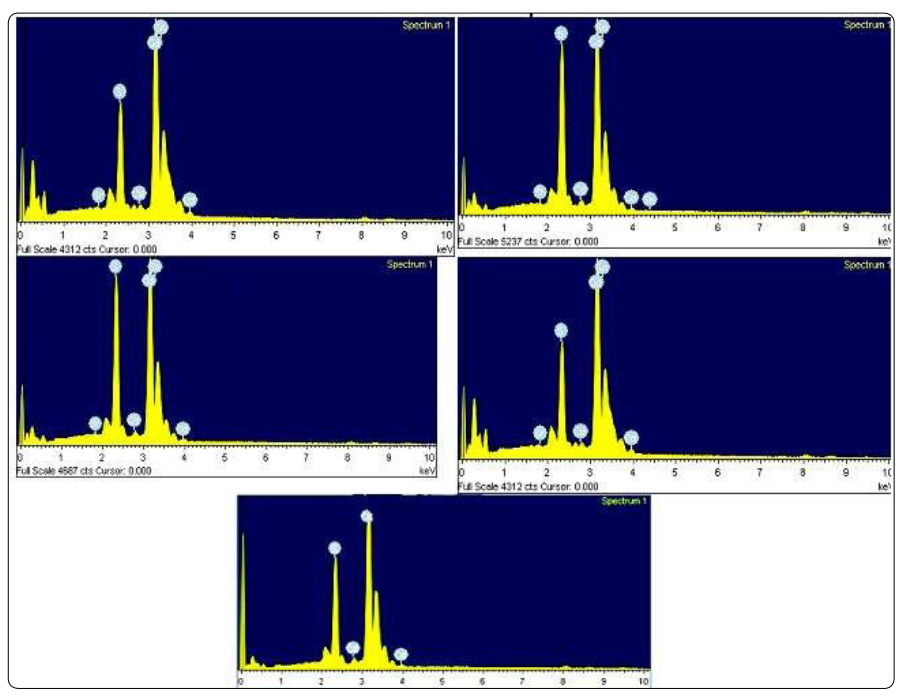

Figure 3. EDX images of $A-\left(S_{0.02}, S_{0.08}: C d S\right), B-\left(S_{0.04}, S_{0.06}: C d S\right)$, $C-\left(\mathrm{Sn}_{0.06}, \mathrm{Sr}_{0.04}: \mathrm{CdS}\right), \mathrm{D}-\left(\mathrm{Sn}_{0.08}, \mathrm{Sr}_{0.02}: \mathrm{CdS}\right)$ and E-Pure CdS respectively.
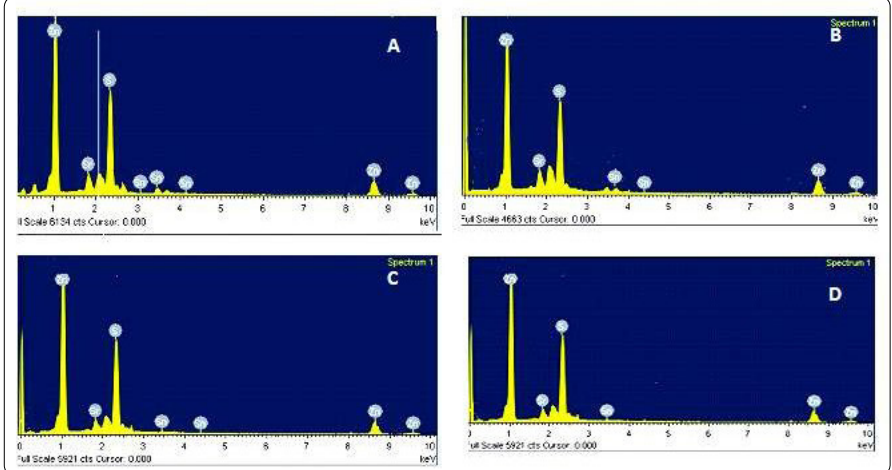

Figure 4. EDX images of $A-\left(\mathrm{Sn}_{0.02}, \mathrm{Sr}_{0.08}: \mathrm{ZnS}\right), \mathrm{B}-\left(\mathrm{Sn}_{0.04}, \mathrm{Sr}_{0.06}: \mathrm{ZnS}\right)$, $\mathrm{C}-\left(\mathrm{Sn}_{0.06}, \mathrm{Sr}_{0.04}: \mathrm{ZnS}\right), \mathrm{D}-\left(\mathrm{Sn}_{0.08}, \mathrm{Sr}_{0.08} \mathrm{ZnS}\right)$ and pure $\mathrm{ZnS}$ respectively.

EDX images of $\mathrm{Sn}$ and $\mathrm{sr}$ doped cadmium and zinc sulphide reveals that the $\mathrm{Sn}$ and $\mathrm{Sr}$ are incorporated in both the crystals of cadmium sulphide and zinc sulphide (Figure 4).

\section{X-ray diffraction (XRD) analysis}

The X-Ray diffraction analysis was carried on PANalytical, the Netherland model $X^{\prime}$ pert pro. The following are XRD images of Sn and Sr doped CdS and ZnS (Figure 5).

From the XRD figure 5 for $\mathrm{Sn}$ and $\mathrm{Sr}$ doped cadmium sulphide. The planes 100, 002, 101, 110, 004 and 211 are the planes for hexagonal crystals of cadmium sulphide. The planes 102,112 and 114 are the planes can be seen in the image of Sn and Sr doped Cadmium Sulphide that is due to the presence of strontium and tin doping.

The same observation can be seen in case of zinc sulphide. The planes 100,111, 101, 002, 200, 311, 400, 331,422 and 511 are the planes of hexagonal wurtzite structure of zinc sulphide. The extra peaks 103 and 420 are present in XRD graph of Sn and $\mathrm{Sr}$ doped zinc sulphide, because of Sn and Sr impurity (Figure 6).

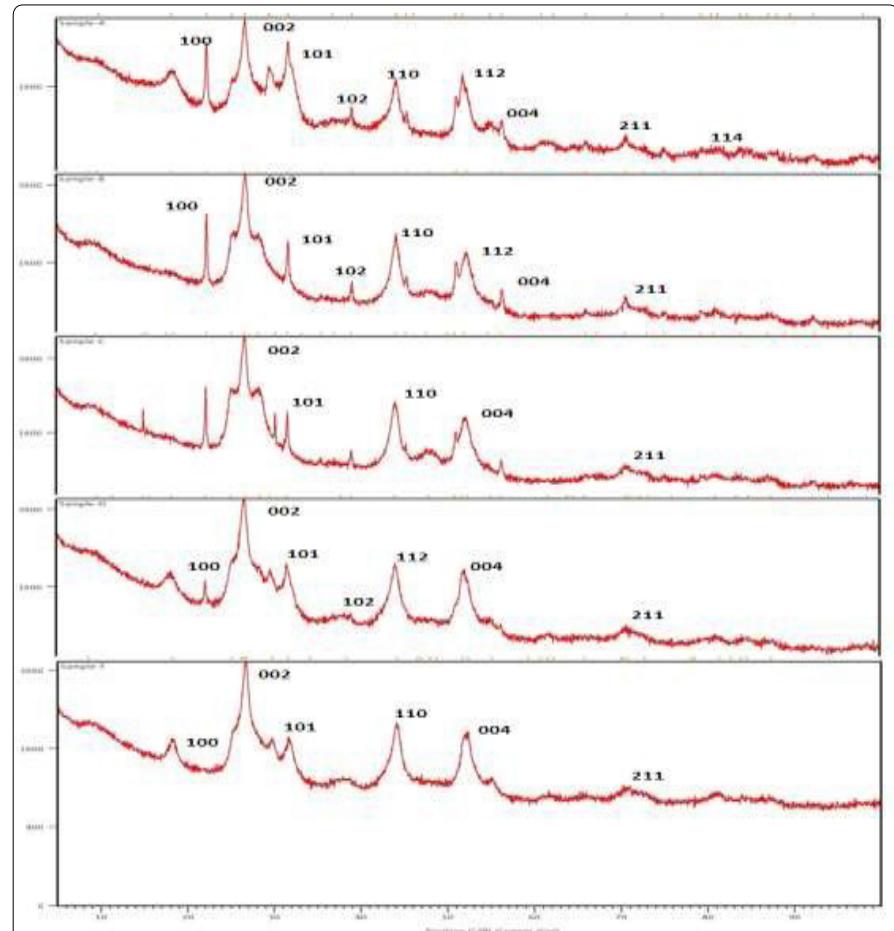

Figure 5. XRD images of $A-\left(\mathrm{Sn}_{0.02}, \mathrm{Sr}_{0.08}: \mathrm{CdS}\right), \mathrm{B}-\left(\mathrm{Sn}_{0.04}, \mathrm{Sr}_{0.06}: \mathrm{CdS}\right)$, $\mathrm{C}-\left(\mathrm{Sn}_{0.06}, \mathrm{Sr}_{0.04}: \mathrm{CdS}\right), \mathrm{D}-\left(\mathrm{Sn}_{0.08}, \mathrm{Sr}_{0.02}: \mathrm{CdS}\right)$ and E-Pure CdS respectively.

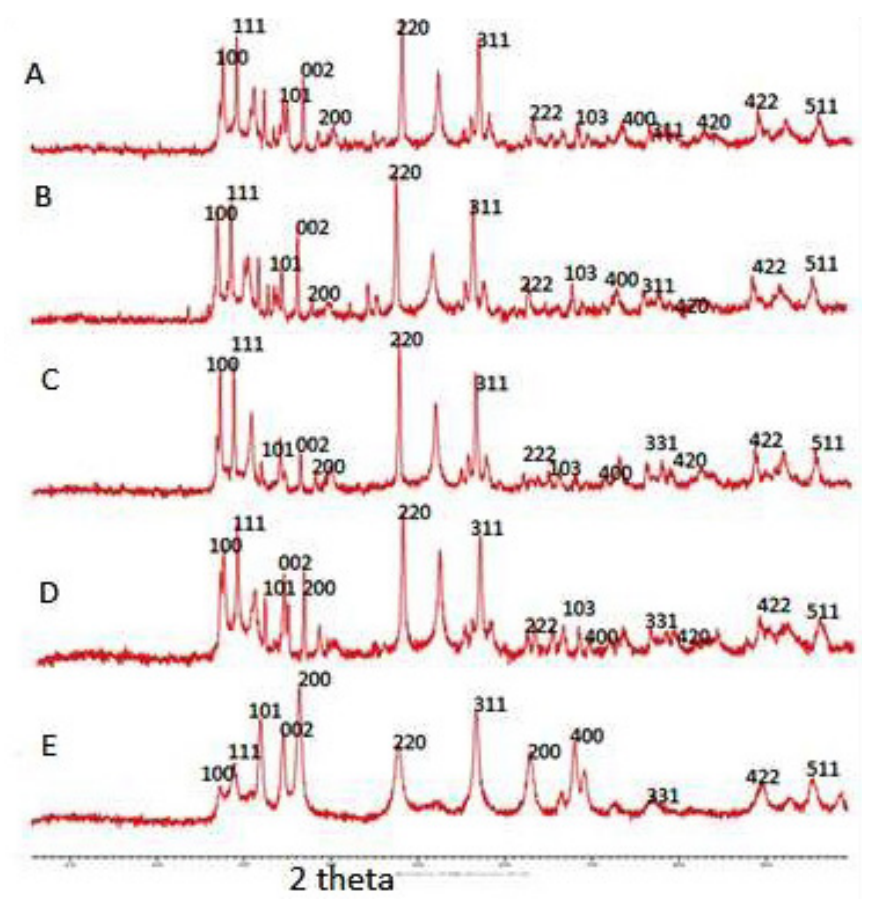

Figure 6. XRD images of $A-\left(\mathrm{Sn}_{0.02}, \mathrm{Sr}_{0.08}: \mathrm{ZnS}\right), \mathrm{B}-\left(\mathrm{Sn}_{0.04}, \mathrm{Sr}_{0.06}: \mathrm{ZnS}\right)$, $\mathrm{C}-\left(\mathrm{Sn}_{0.06}, \mathrm{Sr}_{0.04}: \mathrm{ZnS}\right), \mathrm{D}-\left(\mathrm{Sn}_{0.08}, \mathrm{Sr}_{0.08} \mathrm{ZnS}\right)$ and pure $\mathrm{ZnS}$ respectively.

\section{Antimicrobial activity}

The antimicrobial activity of cadmium sulphide and zinc sulphide was studied by checking the inhibition of Staphylococcus aureus, Escherichia coli, Pseudomonas and Salmonella typhi bacterias. Figure 7 is showing the pictorial inhibition of Staphylococcus aureus, Escherichia coli, Pseudomonas and Salmonella typhi respectively.

The figure 7 is clearly showing the inhibition of bacterias. This result is illustrated in table 1. 


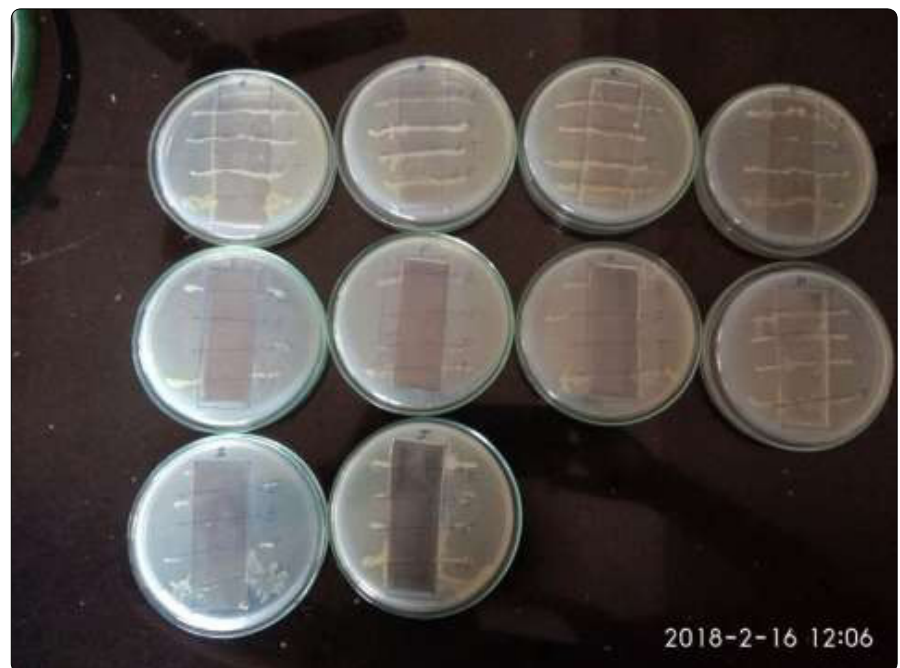

Figure 7. Images of antimicrobial Inhibition for $\mathrm{A}-\left(\mathrm{Sn}_{0.02}, \mathrm{Sr}_{0.08}\right.$ $\mathrm{CdS}), \mathrm{B}-\left(\mathrm{Sn}_{0.04}, \mathrm{Sr}_{0.06}: \mathrm{CdS}\right), \mathrm{C}-\left(\mathrm{Sn}_{0.06}, \mathrm{Sr}_{0.04}: \mathrm{CdS}\right), \mathrm{D}-\left(\mathrm{Sn}_{0.08}\right.$

$\left.\mathrm{Sr}_{0.02}: \mathrm{CdS}\right)$, E-Pure CdS, F-(Sn $\left.0.02, \mathrm{Sr}_{0.08}: \mathrm{ZnS}\right), \mathrm{G}-\left(\mathrm{Sn}_{0.04}, \mathrm{Sr}_{0.06}: \mathrm{ZnS}\right)$,

$\mathrm{H}-\left(\mathrm{Sn}_{0.06}, \mathrm{Sr}_{0.04}: \mathrm{ZnS}\right), \mathrm{I}-\left(\mathrm{Sn}_{0.08}, \mathrm{Sr}_{0.08} \mathrm{ZnS}\right)$ and J- pure $\mathrm{ZnS}$ respectively.

Table 1. Antimicrobial Inhibition for $A-\left(S_{0.02}, S_{0.08}: C d S\right), B-\left(S_{0.04}\right.$ $\left.\mathrm{Sr}_{0.06}: \mathrm{CdS}\right), \mathrm{C}-\left(\mathrm{Sn}_{0.06}, \mathrm{Sr}_{0.04}: \mathrm{CdS}\right), \mathrm{D}-\left(\mathrm{Sn}_{0.08}, \mathrm{Sr}_{0.02}: \mathrm{CdS}\right), \mathrm{E}-\mathrm{Pure} \mathrm{CdS}$, $\mathrm{F}-\left(\mathrm{Sn}_{0.02}, \mathrm{Sr}_{0.08}: \mathrm{ZnS}\right), \mathrm{G}-\left(\mathrm{Sn}_{0.04}, \mathrm{Sr}_{0.06}: \mathrm{ZnS}\right), \mathrm{H}-\left(\mathrm{Sn}_{0.06}, \mathrm{Sr}_{0.04}: \mathrm{ZnS}\right)$, $\mathrm{I}-\left(\mathrm{Sn}_{0.08}, \mathrm{Sr}_{0.08} \mathrm{ZnS}\right)$ and J- pure $\mathrm{ZnS}$ respectively.

\begin{tabular}{|l|c|c|c|c|}
\hline Compound & $\begin{array}{c}\text { Staphylococcus } \\
\text { aureus }\end{array}$ & $\begin{array}{c}\text { Escherichia } \\
\text { Coli. }\end{array}$ & Pseudomonas & $\begin{array}{c}\text { Salmonella } \\
\text { Typhi }\end{array}$ \\
\hline $\mathrm{Sn}_{0.02} \mathrm{Sr}_{0.08} \mathrm{CdS}$ & - & - & - & - \\
\hline $\mathrm{Sn}_{0.04} \mathrm{Sr}_{0.06} \mathrm{CdS}$ & - & - & - & - \\
\hline $\mathrm{Sn}_{0.06} \mathrm{Sr}_{0.04} \mathrm{CdS}$ & - & - & - & - \\
\hline $\mathrm{Sn}_{0.08} \mathrm{Sr}_{0.02} \mathrm{CdS}$ & - & - & - & + \\
\hline $\mathrm{CdS}$ & + & + & + & + \\
\hline $\mathrm{Sn}_{0.02} \mathrm{Sr}_{0.08} \mathrm{ZnS}$ & + & + & + & + \\
\hline $\mathrm{Sn}_{0.04} \mathrm{Sr}_{0.06} \mathrm{ZnS}$ & + & + & - & + \\
\hline $\mathrm{Sn}_{0.06} \mathrm{Sr}_{0.04} \mathrm{ZnS}$ & - & - & - & - \\
\hline $\mathrm{Sn}_{0.08} \mathrm{Sr}_{0.02} \mathrm{ZnS}$ & + & + & + & + \\
\hline $\mathrm{ZnS}$ & + & + & - & + \\
\hline
\end{tabular}

Table 1 and figure 7 data reveals that pure cadmium sulphide has shown inhibition of the all four Staphylococcus aureus, Escherichia coli, Pseudomonas and Salmonella typhi. The Sn and Sr doped cadmium sulphide have no effect on the antimicrobial activity for all four microbes.

In case of zinc sulphide nanoparticles only the compound $\mathrm{Sn}_{0.06} \mathrm{Sr}_{0.04} \mathrm{ZnS}$ has not shown the inhibition of all the bacteria. The remaining doped and undoped ZnS nanoparticles have shown inhibition of four bacterias [4].

\section{Conclusion}

The prepared cadmium sulphide and zinc sulphide nanoparticles doped with $\mathrm{Sn}$ and $\mathrm{Sr}$ are nanosized. The Tin and strontium ions are successfully incorporated in cadmium sulphide and zinc sulphide crystals. The crystals of both cadmium sulphide and zinc sulphide nanoparticles are hexagonal structure confirmed by XRD. The pure cadmium sulphide shows inhibition of Staphylococcus aureus, Escherichia coli, Pseudomonas and Salmonella typhi. Sn and Sr doping have no effect on antimicrobial activity of cadmium sulphide. But the Sn and Sr doped zinc sulphide and pure zinc sulphide show antimicrobial activity.

\section{Conflict of Interest}

There is no conflict of interest.

\section{References}

1. Paulkumar K, Gnanajobitha G, Vanaja M, et al. Piper nigrum leaf and stem assisted green synthesis of silver nanoparticles and evaluation of its antibacterial activity against agricultural plant pathogens. The Scientific World Journal. 2014; 9. doi: 10.1155/2014/829894

2. Othman SH, Abd Salam NR, Zainal N, Basha RK, Talib RA. Antimicrobial activity of TiO2 nanoparticle-coated film for potential food packaging applications. International Journal of Photoenergy. 2014; 6. doi: $10.1155 / 2014 / 945930$

3. Karvani ZE, Chehrazi P. Antibacterial activity of $\mathrm{ZnO}$ nanoparticle on gram-positive and gram-negative bacteria. African Journal of Microbiology Research. 2011; 5(12): 1368-1373. doi: 10.5897/AJMR10.159

4. Kumar MS, Saroja M, Venkatachalam M, Rajamanickam T. Antimicrobial Activity and Photocatalytic Degradation Properties of Zinc Sulfide Nanoparticles Synthesized by using Plant Extracts. Journal of Nanostructures. 2018; 8(2): 107-118.

5. Yemmireddy VK, Hung YC. Using Photocatalyst Metal Oxides as Antimicrobial Surface Coatings to Ensure Food Safety-Opportunities and Challenge. Comprehensive Reviews in Food Science and Food Safety. 2017; 16(4): 617-631. doi: 10.1111/1541-4337.12267

6. Cushnie TPT, Lamb AJ. Antimicrobial activity of flavonoids. Int J Antimicrob Agents. 2005; 26(5): 343-356. doi: 10.1016/j.jjantimicag.2005.09.002

7. Hammer KA, Carson CF, Riley TV. Antimicrobial activity of essential oils and other plant extracts. J Appl Microbiol. 1999; 86(6): 985-990. doi: 10.1046/j.1365-2672.1999.00780.x

8. Nathan, Carl F, John B. Hibbs Jr. Role of nitric oxide synthesis in macrophage antimicrobial activity. Curr Opin Immunol. 1991; 3(1): 65-70. doi: 10.1016/0952-7915(91)90079-G 